\title{
THE
}

\section{Data Body Milieu: The Latinx Immigrant at the Center of Technological Development}

\author{
Melissa Villa-Nicholas \\ University of Rhode Island, mvnicholas@uri.edu
}

Follow this and additional works at: https://digitalcommons.uri.edu/lsc_facpubs

The University of Rhode Island Faculty have made this article openly available.

Please let us know how Open Access to this research benefits you.

This is a pre-publication author manuscript of the final, published article.

Terms of Use

This article is made available under the terms and conditions applicable towards Open Access Policy Articles, as set forth in our Terms of Use.

\section{Citation/Publisher Attribution}

Villa-Nicholas, M. (2019). Data Body Milieu: The Latinx Immigrant at the Center of Technological Development. Feminist Media Studies, 20(2), 300-304. doi: 10.1080/14680777.2020.1720351

Available at: https://doi.org/10.1080/14680777.2020.1720351

This Article is brought to you for free and open access by the Graduate School of Library and Information Studies at DigitalCommons@URI. It has been accepted for inclusion in Graduate School of Library and Information Studies Faculty Publications by an authorized administrator of DigitalCommons@URI. For more information, please contact digitalcommons-group@uri.edu. 
Data Body Milieu: The Latinx Immigrant at the Center of Technological Development Melissa Villa-Nicholas

University of Rhode Island

\section{Introduction}

We are increasingly seeing the Latinx immigrant body in U.S.-Mexico borderlands engaged as the surface for which information technology is mobilized. Recent investment in the collection of biodata on the border has become a highly profitable grab of immigrants' data. The surveillance of Latinx immigrants and development of technology around the Latinx body is not new (Iván Chaar-Lopez 2019), but what has changed is its scale and economic value. This article aims to explore the new state of data body milieu, wherein all residents in the U.S. are intimately entwined in data surveillance gathering in the name of belonging and citizenship, centering technological development around the anxiety and information processing of immigrants and refugees.

Digital borderland technology engages a new citizen identity wherein everyone in the U.S. is now a part of the U.S.-Mexico borderland milieu (Oscar Martinez 1994). Through bids for technology to biologically map Latinx immigrants at the border, and subsequently U.S. citizens, there is a promise of futurity in technological design to "fix" the state of citizenship by removing undesired immigrants and refugees.

\section{Data Body Milieu}

In recent years there has been an upsurge in the investment and collection of biological data through biotechnology of immigrants and a reshaping of Silicone Valley around borderlands investment (Chaar-Lopez 2019). Truthout estimates that data gathering on the U.S. Mexico border will be a $\$ 740$ billion industry by 2023 (Michelle Chen 2019). With surveillance 
technologies, undocumented people are positioned as mappable and more valued subjects through their biological data. This feverish move to collect data of undocumented people designs technology around tampering the "Latinx Threat"” (Leo R. Chávez 2008) and promises and future without Latinx immigrants.

Felix Stalder first named the "data body" as a shadow body that precedes and follows us with classification and measurement (2009). This phenomenon increased with every digitized byte of data from citizen consumer's credit cards, grocery purchases, online bill payment (Felix Stalder 2009), and has since become quotidian in citizen consumer engagement. This data body allows for the increase in life chances (such as health care eligibility and home loans), the more the citizen is digitally mappable, the more the citizen becomes digitally and capitally valuable. But the undocumented person, without data, acts as a threat to the state of the citizen consumer, and this surveillance technology.

In the physical borderlands, immigrants and citizens have long had frictitious and productive relationships. Oscar J. Martínez's "Borderlands Milieu” observed that "By nature all borderlands, regardless of their location or level of interaction, function in an environment --here called the borderlands milieu --- that springs from boundary-related phenomena" (Martínez 1994, 25). About borderland milieu Martínez goes on to say:

As the peripheries of nations, borderlands are subject to frontier forces and international influences that mold the unique way of life of borderlands, prompting them to confront myriad challenges stemming from the paradoxical nature of the setting in which they live. Borders simultaneously divide and united, repel and attract, separate and integrate (Martínez 1994, 25). 
Indeed, now two-thirds of the United States has been named a digital "borderland" defined by the Trump administration as anyone within 100 miles of a border (including oceans) as susceptible to the use of borderland surveillance technology (Olivia Solon 2018).

But these citizens of the borderlands do not experience the same frictions and opportunities of the physical border once observed by Martinez. They are not engaged in the same intimate experiences of Southwest (and other geographic areas with increasing immigrant populations) relationships.

This is a different state of milieu, the data body milieu.

The data body milieu is the state of surveillance that brings all people, citizen and immigrant, into an intimate place of surveillance wherein our data lives together and defines us in a digital borderland, and uses the Latinx immigrant as catalyst for technological growth.

\section{Immigrant Data}

In March 2018, Congress approved the \$1.3-billion budget for the 1,954 miles of virtual “smart" border wall (Kristina Davis 2019). Rhetoric surrounding the virtual border wall included promises beyond the physical border wall: not only would immigrants be kept out of the U.S., but they could now be known, be documented through digital technology's biological mapping.

The coding of these technologies is built around the gaze of the Latinx undocumented person as the object to capture, therefore making the Latinx immigrant body the center of information technology design (Coolfire Solutions 2018). Technology for the self-driving car 3D technology is being promoted by Quanergy Systems to create a 3D border wall that biomaps bodies through laser-based detection (CNBC 2018). DNA Test kits are used by border patrol to test all undocumented people in the border, justified as a means of "identifying" fake family members (Priscilla Alvarez 2019). Amazon's cloud services are authorized to house all data 
scanned in by ICE and Homeland Security (Who is Behind ICE 2019). There is no resolution as to who owns the data in the U.S.; however, they continue to build an emerging database of mappable biological data.

This new state of data body milieu moves undocumented immigrants and refugees from valued as exploitable forms of labor in the U.S., to information products in and of themselves. They are now not valued for their potential to be captured and moved back to their country, but their value lies in their data in and of itself.

\section{White Silicone Valley as Hero}

Data body milieu is a state that can code in immigrants and refugees as illegal and villainous, and designs the tech company itself as the hero of a story arc.

The whiteness embedded in Silicon Valley (Noble and Sarah Roberts 2019) technology design is manufactured into the digital border wall and borderland surveillance technologies. Whiteness and citizenship are deemed as the markers of heroic users of surveillance technologies. Undocumented Latinx people are interpellated through design as "villains." Palantir's Gotham Industries has since built a database of anyone with a criminal record, their namesake referring to the crime-ridden city of DC's Batman (Palantir n.d.). Oculus' founder Palmer Luckey's company, Anduril Industries has won a large bid for the digital border wall (Taylor Hatmaker 2019). The reference to "Anduril" is a powerful sword in Lord of the Rings used by Aragorn, a hero of the story, against the villains, in this scenario the undocumented person in the borderlands. Border patrol currently uses virtual reality goggles that scan the border using the infrastructure of surveillance towers (George Joseph 2017). These goggles are designed as the first person video game Call of Duty, wherein undocumented people on borderlands are cast as enemies in a modern warfare situation, and the user of the VR Goggles (border patrol 
agents) are positioned as the U.S. or its allies, the "good guys" or heroes, in any given war from history (Lauren Etter and Karen Weise 2018).

In data body milieu, the capture of these villains is centered in the capture and housing of their data body, rather than the corporal body.

\section{The Designed Latinx "Good Citizen"}

In this state of data body milieu, the purpose is not to remove Latinxs all together but to design the acceptable form of Latinidad U.S. citizens. The inverse to the digital border has emerged around the Latinx body, which is the visible Latinx subject designed as AI.

These anthropomorphized virtual agents (AVAs) demonstrate acceptable forms of Latinx citizenship: they are designed to speak English first, Spanish second; are modeled as lighter skin Latinas with straight hair; and positioned in digital borderlands of the USCIS Website and Southwest borderland airports (Villa-Nicholas and Miriam Sweeney 2019). These AVAs are designed as a "Good Citizen" (Villa-Nicholas and Sweeney 2019) --- one that encompasses the "Latino Look" historically established as desirable in U.S. media (Arlene Dávila 2012). Latina AVAs at borderland airports are coded and sold as "not illegal": they are pitched around the language of "not needing documentation", they can work 24 hours a week, and are sold as cheaper than human labor (Sweeney and Villa-Nicholas 2019). In the state of data body milieu, if Latinx immigrants cannot assimilate, they can be designed into assimilation.

\section{Conclusions}

Data body milieu also lies in the murky unknowns of citizen consumers' data. For example: is the data from Amazon's "Alexa" housed in the same Amazon cloud service as the data of undocumented people in detention centers? U.S. citizens and undocumented people are 
now intimately connected through the uncertainty of where their data lives, as well as the value of data in and of itself. That is the ubiquity of data body milieu.

This essay begins an observation of the state of data body milieu, a state wherein immigrant data is a central organizing tool of technological design. This concept needs examination beyond Latinx U.S.-border technologies and is open to evolving definition, however not without direct resistance to marginalization. In Feminist Media Studies we may consider the data body more seriously as part of our own physical bodies. And that the treatment of our data, biological and informative, can now be cast with as much theorizing around race, gender, sexuality and class, as the physical. Our data body, somewhere, out there, is in constant formation and definition in this observed state of data body milieu.

Discussion around data body milieu requires full advocacy for the information rights of undocumented people. As senate bills S. 2462 and S.823 move forward to protect citizens from borderland surveillance technology (Sophie Cope 2018), we must prioritize undocumented people's data rights in U.S. policy.

\section{References}

Alvarez, Priscilla. 2019. "ICE ramps up DNA testing for migrant families along the southern border. CNN. July 22. Accessed July 22, 2019.

https://www.cnn.com/2019/07/22/politics/ice-deploys-dna- testing-at-border/index.html

Chaar-López, Iván. 2019. "Sensing Intruders: Race and the Automation of Border Control.” American Quarterly, 71(2): 495-518.

Chávez, Leo R. 2008. The Latino Threat: Constructing Immigrants, Citizens, and the Nation. Stanford: Stanford University Press.

Chen, Michelle. 2019. "The US border security industry could be worth $\$ 740$ billion by 2023." Truthout. October 6, Truthout.org. Accessed October 5, 2019. https://truthout.org/articles/the-us-border-security-industry-could-be-worth-740-billion-by-2023/

Cope, Sophie. 2018. "Senators introduce new bill to protect digital privacy at the 
border." March 9, 2018. Electronic Frontier Foundation (EFF).

https://www.eff.org/deeplinks/2018/03/senators-introduce-new-bill-protect-digital-

privacy-border

Coolfire Solutions. 2018. "A digital wall could be the answer to U.S. border security." Coolfire Solutions. December 10, 2018. Coolfire Solutions Webpage.

https://www.coolfiresolutions.com/blog/mexico-us-border-security-digital-wall/

CNBC. December 17, 2018. "These Virtual Walls could be the Cheaper More Effective Answer to Trumps $\$ 5$ Billion Border Wall.” CNBC Website.

https://www.cnbc.com/video/2018/12/14/this-border-town-doesnt-want-trumps-wall-but-a-

silicon-valley-virtual-wall-could-stand-strong.html

Dávila, Arlene. 2012. Latinos, Inc. Oakland: University of California Press.

Davis, Kristina. 2019. "How would a 'smart wall' work at the U.S.-Mexico norder?" Los Angeles Times. March 24, 2019. Los Angeles Times. https://www.latimes.com/local/lanow/la-me-ln-smart-border-wall-20190324-story.html

Etter, Lauren and Weise, Karen. 2018. "The race the cash in on Trump's invisible high-tech border wall.” Bloomberg. April 9, 2018.

George, Joseph. 2017. The biometric frontier: Show me your papers' becomes 'Open your eyes' as border sheriffs expand iris surveillance. The Intercept. August 7, 2017. https://theintercept.com/2017/07/08/border-sheriffs-iris-surveillance-biometrics/

Hatmaker, Taylor. 2019. "Palmer Luckey’s surveillance startup already worth \$1B: Report." Daily Beast. September 11, 2019. https://www.thedailybeast.com/anduril-palmerluckeys-surveillance-startup-is-already-worth-dollar1b-report

Martinez, Oscar. 1994. Border People: Life and Society in the U.S.-Mexico Borderlands. Tucson: The University of Arizona Press.

Noble, Safiya and Roberts, Sarah. 2019. "Technological elites, the mertiocracy, and postracial myths in Silicon Valley.” UCLA. https://escholarship.org/uc/item/7z3629nh

Palantir. N.D. Gotham Website. https://www.palantir.com/palantir-gotham/

Stalder, Felix. 2009. "Privacy is not the antidote to surveillance." Surveillance \& Society. 1(1).

S.823- Protecting Data at the Border Act. Congress.gov.

Solon, Olivia. 2018 “'Surveillance society': Has technology at the US-Mexico border gone too far?" The Guardian. June 13, 2018.

Sweeney, Miriam and Villa-Nicholas, Melissa. "Cultural affordances of 'Emma,' USCIS's 
latina virtual assistant. Harvard Digital Kennedy School Lecture Series. March 25, 2019. https://vimeo.com/331443862

Villa-Nicholas, Melissa. 2019. "Missing Cells: The Growing Economic Value of Immigrant and Refugee Biological Data." Bitch Media. December 19, 2019. https://www.bitchmedia.org/article/government-storing-biometric-data-immigrantsrefugees

Villa-Nicholas, Melissa and Sweeney, Miriam. 2019. "Designing the 'Good Citizen' through USCIS's virtual assistant 'Emma."” Feminist Media Studies. https://www.tandfonline.com/doi/full/10.1080/14680777.2019.1644657

Who's Behind ICE? The tech and data companies fueling deportations. 2018. Mijente, the National Immigration Project, and the Immigrant Defense Project . https://mijente.net/2018/10/23/whos-behind-ice-the-tech-companies-fueling-deportations/ 